\title{
ARTICLE
}

\section{Multi-model inference for growth parameter estimation of the Bigeye Croaker Micropogonias megalops in the Upper Gulf of California}

Inferencia con modelos múltiples para la estimación de parámetros de crecimiento del Chano norteño Micropogonias megalops en el Alto Golfo de California

\section{E. Alberto Aragón-Noriega ${ }^{1}$, Edgar Alcántara-Razo', Wenceslao Valenzuela-Quiñónez ${ }^{2}$ and Gerardo Rodríguez-Quiroz ${ }^{2}$}

\begin{abstract}
${ }^{1}$ Centro de Investigaciones Biológicas del Noroeste, Unidad Sonora, Km 2.35 Camino al Tular, Estero Bacochibampo, Guaymas, Sonora 85454, México. aaragon04@cibnor.mx

${ }^{2}$ Departamento de Acuacultura, Instituto Politécnico Nacional-CIIDIR, Unidad Sinaloa, Boulevard Juan de Dios Bátiz Paredes \# 250, Guasave, Sinaloa 81101, México

Resumen.- El chano norteño Micropogonias megalops es capturado en el Alto Golfo de California (AGC) por comunidades de pescadores locales de San Felipe en Baja California, El Golfo de Santa Clara y Puerto Peñasco en Sonora, México. Para la administración sustentable de la pesquería, es necesario conocer el crecimiento de la especie. Se calculó el crecimiento individual de M. megalops del AGC usando 4 ecuaciones: la ecuación de crecimiento de von Bertalanffy (ECVB), Logístico, Gompertz y Schnute. Los parámetros de cada modelo y los intervalos de confianza (IC) fueron calculados usando el método de máxima verosimilitud. El mejor modelo se seleccionó con el criterio de información de Akaike (CIA). Según el CIA, la ECVB es la que mejor describe los datos. Los parámetros y sus IC fueron: 1) Longitud asintótica promedio ( $L_{\infty}$ ) en machos $429 \mathrm{~mm}$ de longitud total LT (IC 426-432 mm LT) y en hembras $461 \mathrm{~mm} \mathrm{LT} \mathrm{(IC} \mathrm{457-464} \mathrm{mm} \mathrm{LT);} \mathrm{2)} \mathrm{el} \mathrm{coeficiente} \mathrm{de} \mathrm{crecimiento} \mathrm{(} \mathrm{k}$ ) en machos 0,419 (IC 0,412-0,426) y en hembras 0,377 (IC 0,370-0,384). En conclusión, la ECVB describe adecuadamente el crecimiento individual de $M$. megalops en el AGC.
\end{abstract}

Palabras clave: Crecimiento, modelos múltiples, teoría de información de Akaike, Alto Golfo de California, Micropogonias megalops, von Bertalanffy

\begin{abstract}
Bigeye Croaker (Micropogonias megalops) is caught in the Upper Gulf of California (UGC) by local community fishermen from San Felipe in Baja California, Golfo de Santa Clara and Puerto Peñasco in Sonora, Mexico. For the sustainable management of this fishery, it is necessary to understand its growth cycle. We modeled the individual growth of $M$. megalops from the UGC using 4 growth models: von Bertalanffy growth model (VBGM), Logistic, Gompertz and Schnute. The parameters of each model and their confidence intervals $(\mathrm{Cl})$ were computed using the maximum-likelihood method. The best-fit model was selected using Akaike's information criterion (AIC). According to AIC, the VBGM model fit best the data. The parameter estimated and $\mathrm{Cl}$ were: 1 ) mean asymptotic length $\left(\mathrm{L}_{\infty}\right)$ in males $429 \mathrm{~mm}$ total length $\mathrm{TL}(\mathrm{Cl}$ 426-432 $\mathrm{mm} \mathrm{TL})$ and in females $461 \mathrm{~mm}$ TL (Cl 457-464 mm TL); 2) the growth coefficient ( $\mathrm{k}$ ) in males 0.419 (Cl 0.412-0.426) and in females 0.377 (Cl 0.370 0.384). In conclusion, the VBGM adequately described the individual mean growth for $M$. megalops in the UGC.
\end{abstract}

Key words: Growth, Multi-Model inference, Akaike information theory, Upper Gulf of California, Micropogonias megalops, von Bertalanffy

\section{INTRODUCTION}

The Bigeye Croaker, Micropogonias megalops (Gilbert, 1890), is a coastal bottom-dwelling fish (Varela-Romero \& Grijalva-Chon 2004) that is endemic to the Gulf of California (Castro-Aguirre 1978, Chao 1995). The fishery became commercial in the Upper Gulf of California (UGC) in 1991 (Fig. 1) as a socioeconomic alternative to shrimp when their catch rates dropped. This fish was first caught using larger vessels; however, since 1992, small boats have comprised $15.46 \%$ of the overall catch. The Bigeye Croaker fishery represents approximately $27 \%$ of volume of the fish species captured in the UGC. Based on catch volume and onshore economic value, this is one of the 5 most important fisheries in the UGC (Rodríguez-Quiroz 2010).

Bigeye Croaker are caught from March to August (Fig. 2 ), which is when the species migrates into the area to 


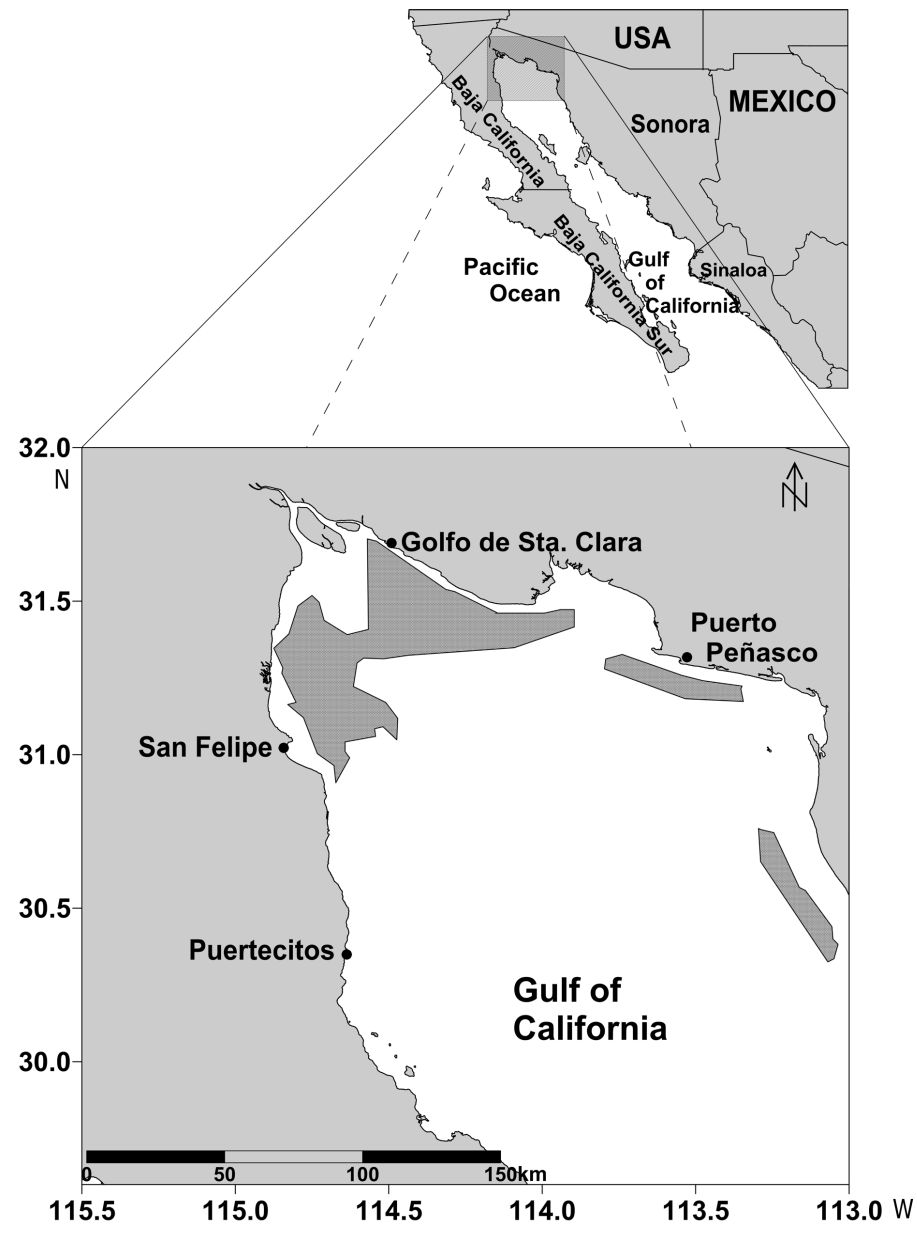

Figure 1. Fishing ground of Bigeye Croaker Micropogonias megalops and locations of the main fishing communities / Áreas de pesca de Chano norteño Micropogonias megalops y localización de las principales comunidades de Pescadores

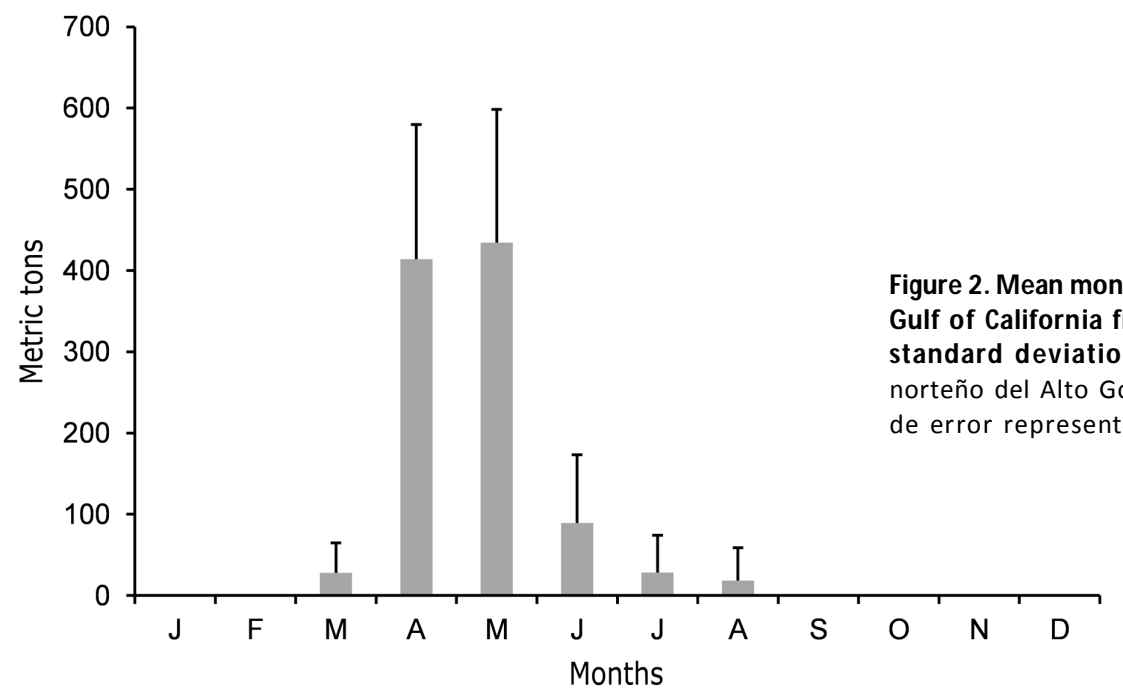


form aggregations and spawn, and the catch conforms to economic and market necessities. Before the high demand for Bigeye Croaker for the surimi industry in Korea there was no Bigeye Croaker fishery, after this fishery come out the old traditional fisheries get relaxed from the high exploitation (Cudney \& Turk 1998). Bigeye Croakers are caught in the UGC by local community fishermen from San Felipe in Baja California, El Golfo de Santa Clara and Puerto Peñasco in Sonora, Mexico. Overall catches of 2900 MT in 1998 fell to 596 MT in 2002 and have since begun to rebound (Fig. 3). The sustainable fishery index (SFI) calculated by Aragón-Noriega et al. (2009) identifies 4 production periods: one of low capture before 1999 (1451.49 MT year-1); a second of fleet expansion (2408 t year $^{-1}$ ); a third showing a production decline related to overfishing (923.85 $\mathrm{t} \mathrm{year}^{-1}$ ); and a fourth of recovery, with a standardization of catch yield at approximately 1057 MT year-1 (2004). Aragón-Noriega et al. (2009) made a Geographic Information System (GIS) survey showing that almost $84 \%$ of the Bigeye Croaker fishery in the UGC occurs within 2 marine protected areas, of which almost $74 \%$ occurs inside the UGC Biosphere Reserve and 79\% occurs in the Vaquita Refuge Area. Bigeye Croaker caught in marine protected areas generates a gross profit of approximately US $\$ 501,000$ year $^{-1}$ with a return rate close to $73 \%$. A lack of fishery regulations, misinformed local fishermen regarding those regulations, over-fishing by commercial trawlers, poor flows in the Colorado River and illegal fishing are all leading to declining catches and are jeopardizing the permanency and sustainability of this fishery in the UGC (Galindo-Bect et al. 2000, Varela-
Romero \& Grijalva-Chon 2004, Aragón-Noriega et al. 2009).

Effective fishery management requires a detailed understanding of stock assessment and population dynamics. Therefore, an analysis of the growth parameters of individuals is necessary. The most popular and commonly applied model among the range of individual growth models is the von Bertalanffy growth model (VBGM). Katsanevakis \& Maravelias (2008) have demonstrated that the use of multi-model inference (MMI) is a better alternative than the a priori use of VBGM, and this approach has been adopted by many authors (Zhu et al. 2009, Alp et al. 2011, Baer et al. 2011, Mercier et al. 2011). The literature provides alternatives to the VBGM, such as the Gompertz growth model, Logistic model (Ricker 1975), Schnute model (Schnute 1981), and SchnuteRichards model (Schnute \& Richards 1991). When more than one model is used, model selection is usually based on the shape of the anticipated curve, biological assumptions, and fit of the data. Parametric inference and estimation as well as the precision of these estimates are based solely on the fitted model. Another approach is to fit more than one model and select the best model based on information theory. This approach has been recommended as a more robust alternative when compared with more traditional approaches (Katsanevakis 2006). The most common information-theory approach is to use the Akaike information criterion (AIC) (Katsanevakis 2006, Wang \& Liu 2006, Katsanevakis \& Maravelias 2008, Zhu et al. 2009, Cerdenares et al. 2011, Cruz-Vásquez et al. 2012).

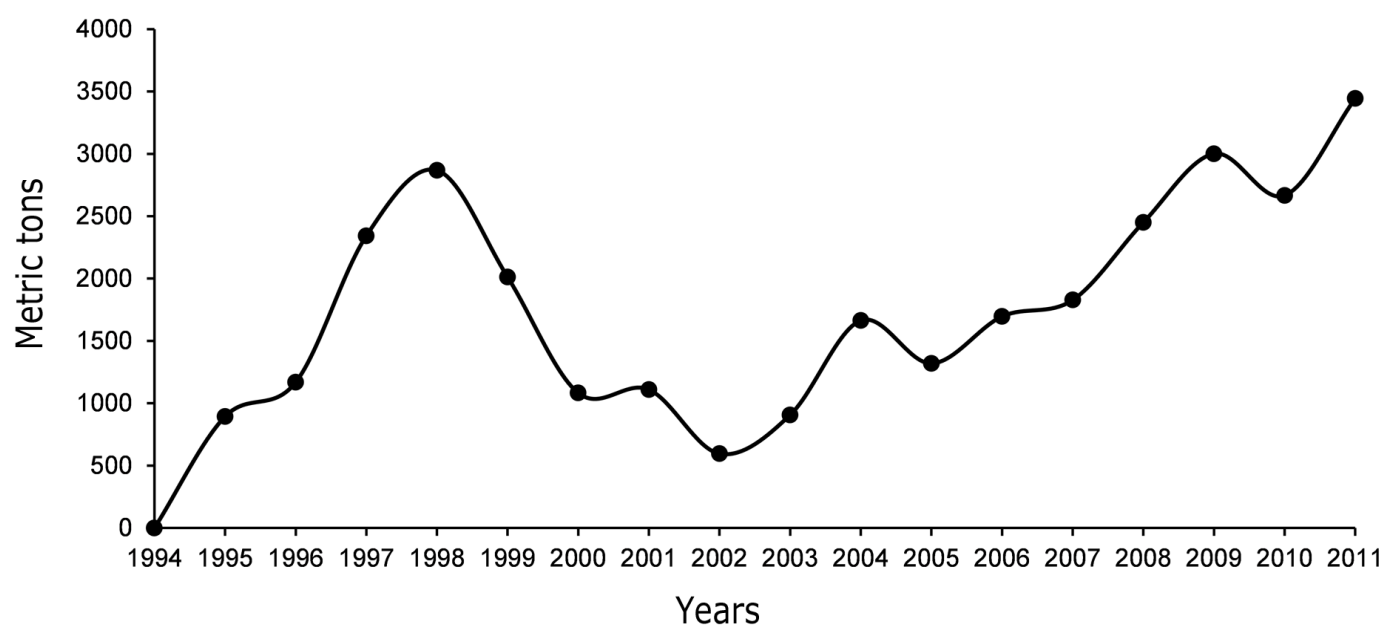

Figure 3. Annual landings of Bigeye Croaker in the area according to official records for the $\mathbf{3}$ main fishing towns / Captura anual de Chano norteño en el área, de acuerdo a los registros oficiales en los 3 campos pesqueros principales 
Therefore, the aim of this work is twofold: on one hand, to determine the growth parameters of the Bigeye Croaker in the UGC using a multi-model approach, and 2, to figure out which model fits best the length-at-age raw data. The resulting growth parameters will be compared versus those obtained by Arzola-Sotelo (2013) whom gets growth parameter of $M$. megalops in a period of 12-14 years later (2010-2012) and try to elucidate possible effect of fisheries over growth parameters. The rationale behind the selection of these objectives was as follows: The only one previous study (Román-Rodríguez 2000) that has reported $M$. megalops growth parameters seems to be erroneously computed or reported. An exceptional opportunity to compare growth parameter at the early catches years versus growth parameters after fishery stress (AragónNoriega et al. 2009) arises since Arzola-Sotelo (2013) reported a similar study after 12 years of the present study data.

\section{MATERIALS AND METHODS}

\section{Data Source}

Length-at-age of Bigeye Croaker from the UGC were obtained from the CONABIO database (Banco de Datos, SNIB-CONABIO) $)^{1}$, as in Roman-Rodríguez (2000). For more detailed information about the sampled period, number of fish sampled by month, number of years, and number of fish sampled by sex, see the online spreadsheet on the website mentioned above. In short, the data are 1012 samples of Bigeye Croaker that were obtained from artisanal fishery vessels during the period of January to May in 1997 and June to August in 1998 in the Gulf of Santa Clara, Sonora, Mexico in the Biosphere Reserve of the Upper Gulf of California and Colorado River Delta. Otoliths were prepared as it is described by RomanRodríguez (2000). Every pair of otoliths were washed, measured and weighted describing their length $(\mathrm{mm})$, width $(\mathrm{mm})$ and weight $(\mathrm{g})$, and kept in envelops with their respective field and organism data. Age was estimated by counting the annual growth bands deposited in the sagittal otoliths, which were covered with epoxy resin and cut it in transversal through the center of the otolith $(2-2.5 \mathrm{~mm})$ to read the growth bands. The total lengths of 664 individuals measured were used to model Bigeye Croaker growth at size and age groups, capture area and gender. The data used are the raw combined data from the directed fishery and from by- catch fisheries. The Bigeye Croaker fishery targets larger fish, including fish that may be larger than average size at age, whereas the by-catch fisheries target smaller fish and possibly fish smaller than average size at age.

\section{MODEL SELECTION AND INFERENCE ABOUT INDIVIDUAL GROWTH}

The information theory approach was used to determine the model that fits the data best as well as to estimate individual growth parameters (Schnute \& Groot 1992, Katsanevakis 2006, Katsanevakis \& Maravelias 2008). We selected a set of 4 models to address the length at age data and determined which model was best. These models were the VBGM (Eq. 1), Logistic model (Eq. 2), Gompertz growth model (Eq. 3), Schnute model (Schnute 1981) (Eq. 4).

The VBGM is given by:

$$
L(t)=L_{\infty}\left(1-e^{-k\left(t-t_{0}\right)}\right)
$$

The logistic growth equation is given by:

$$
L(t)=L_{\infty}\left(1-e^{-k_{2}\left(t-t_{1}\right)}\right)^{-1}
$$

The Gompertz growth equation is given by:

$$
L(t)=L_{\infty}\left(e^{-e^{-k_{3}\left(t-t_{2}\right)}}\right)
$$

In these models, the following parameters are used:

$L(t) \quad$ is length at age $t$ (total length $\mathrm{mm}$ )

$t \quad$ is age (years)

$L_{\infty} \quad$ is the asymptotic length (total length $\mathrm{mm}$ )

$k$ determines how fast $L_{\infty}$ is reached (growth coefficient)

$t_{0} \quad$ is the hypothetical age at size zero (initial condition parameter)

$k_{2} \quad$ is a relative growth rate parameter

$t_{1} \quad$ is the inflection point of the sigmoid curve

$t_{2} \quad$ is $\frac{\operatorname{Ln} \lambda}{K_{3}}$

$\lambda$ is the theoretical initial relative growth rate at zero age (with units of $\mathrm{yr}^{-1}$ )

$k_{3} \quad$ is the rate of the exponential decrease of the relative growth rate with age (with units of $\mathrm{yr}^{-1}$ )

${ }^{1}<$ http://www.conabio.gob.mx/institucion/cgi-bin/datos.cgi?Letras=L\&Numero=298> 
The Schnute (1981) growth model takes 4 mathematical forms. In this study, we use the case 1 model (Eq. 4) when $\lambda \neq 0, \rho \neq 0$,

$$
L(t)=\left[l^{\rho}+\left(\delta^{\rho}-l^{\rho}\right) \frac{1-e^{-\lambda\left(\tau-\tau_{1}\right)}}{1-e^{-\lambda\left(\tau_{2}-\tau_{1}\right)}}\right]^{\frac{1}{\rho}}
$$

$\tau_{1} \quad$ is the lowest age in the dataset

$\tau_{2} \quad$ is the highest age in the dataset

$\lambda \quad$ is a relative growth rate (time constant)

$\rho \quad$ is an incremental relative growth rate (incremental time constant)

$l \quad$ is the size at age $\tau_{1}$

$\delta \quad$ is the size at age $\tau_{2}$

To compute $L_{\infty}$ using the Schnute model, it is necessary use the following Eq. (5).

$$
L_{\infty}=\left[\frac{e^{\lambda \tau_{2}} \delta^{\rho}-e^{\lambda \tau_{1}{ }_{\iota} \rho}}{e^{\lambda \tau_{2}}-e^{\lambda \tau_{1}}}\right]^{\frac{1}{\rho}}
$$

The models were fit using the maximum likelihood method. Additive and multiplicative error structures were considered. The maximum likelihood-fitting algorithm was based on the Eq. (6)

$$
L L(\Phi \mid \text { data })=-\left(\frac{n}{2}\right)(\operatorname{Ln}(2 \pi)+2 * \operatorname{Ln}(\sigma)+1)
$$

where $\Phi$ represents the parameters of the models and $\sigma$ represents the standard deviations of the errors calculated using the following Eq. (7 and 8).

$$
\begin{gathered}
\sigma=\sqrt{\sum \frac{\left(L n L_{o b s}-L n \hat{L}\right)^{2}}{n}} \text { for multiplicative error } \\
\sigma=\sqrt{\sum \frac{\left(L_{o b s}-\hat{L}\right)^{2}}{n}} \text { or additive error }
\end{gathered}
$$

Model selection was performed using the bias-corrected form (AIC , Eq. 9) of the AIC (Eq. 10) (Hurvich \& Tsai 1989, Shono 2000, Burnham \& Anderson 2002, Katsanevakis 2006, Katsanevakis \& Maravelias 2008). The model with the lowest $\mathrm{AIC}_{\mathrm{c}}$ (Eq. 9) value was selected as the best model.

$$
A I C_{C}=A I C+(2 k(k+1) /(n-k-1)
$$

and

$$
A I C=-2 L L+2 k
$$

where

$L L \quad$ is the negative log likelihood

$n \quad$ is the number of observations

$k \quad$ is the number of parameters in each model

For all models, the differences between the $\mathrm{AIC}_{\mathrm{c}}$ values were calculated using

$$
\Delta_{\mathrm{i}}=\mathrm{AIC}_{\mathrm{i}}-\mathrm{AIC}_{\min }
$$

Models with an $\Delta_{\mathrm{i}}>10$ are not supported by the data and should not be considered for parameter estimation; this criterion was proposed by Burnham \& Anderson (2002).

For each model, $i$, the plausibility was estimated using the following Eq. (11) for the Akaike weight:

$$
w_{i}=\frac{\exp \left(-0.5 \Delta_{i}\right)}{\sum_{k=1}^{5} \exp \left(-0.5 \Delta_{k}\right)}
$$

Following a MMI approach, the 'average' $L_{\infty}$ was calculated as the sum of the product of the $L_{\infty}$ parameter multiplied by the corresponding $w_{i}$ for all acceptable models (Eq. 12) as follows:

$$
\bar{L}_{\infty}=\sum_{i=1}^{5} w_{i} \hat{L}_{\infty, i}
$$

\section{Confidence InTERvaL}

The $95 \%$ confidence interval (CI) of growth model parameters $(\theta)$, were estimated after Venzon \& Moolgavkor (1988) using the likelihood profile method. These estimations are based on chi-square distribution with $d$ degrees of freedom. The confidence interval was defined as all values of $\theta$ that satisfy the inequality

$$
2\left(L(Y \mid \theta)-L\left(Y \mid \theta_{\text {best }}\right)\right)<\chi_{1,1-\alpha}^{2}
$$

where $L\left(Y \mid \theta_{\text {best }}\right)$ is the negative log-likelihood of the fitted value of $\theta$ and $\chi_{1,1-\alpha}^{2}$ are the values of the chi square distribution with 1 degree of freedom $(d)$ at a confidence level of $1-\alpha$. Thus the $95 \% \mathrm{CI}$ for $\theta$ encompass all values between the negative log-likelihood and negative log-likelihood of the best estimate of $\theta$ that is less than $3.84(d=1 ; 3.84)$. When considering more than one parameter, the confidence intervals become wider. 
This only occurs if there is any correlation (covariance) between parameters. Cerdenares et al. (2011) explained that the von Bertalanffy growth model has the parameters correlated. They also proposed that the solution is to compute the likelihood based confidence region estimated from contours of constant log-likelihood over the objective surface. Following the Cerdenares et al. (2011) suggestion, this procedure was applied to the $L_{\infty}$ and $k$ parameters jointly to avoid the problem of parameter correlation. In this case, Equation (13) must satisfy the inequality associated with the $\chi^{2}$ distribution with 2 degrees of freedom, where the reference value is less than 5.99 for 2 parameters.

\section{Results}

A total of 664 Bigeye Croakers were measured and aged (see method section). The total length (TL) ranged from 93 to $490 \mathrm{~mm}$ and averaged $308.8 \pm 7.8 \mathrm{~mm}$ TL. The distribution in bins of $25 \mathrm{~mm}$ TL increments showed that there were 2 predominant groups with lengths at 201-225 $\mathrm{mm}$ TL and 375-400 mm TL (Fig. 4). The estimated age of the fishes ranged from 1 to 16 years (Table 1) with a total length of $460 \mathrm{~mm}$ in the oldest fish. The youngest fish had an average TL of 161.6.5 $\pm 23.8 \mathrm{~mm}$. The smallest individual collected (93 $\mathrm{mm}$ in TL) was undifferentiated (no sexed juvenile) at 1 years of age. The largest fish (490 $\mathrm{mm}$ in TL) was a 12-year-old female.
Table 1. Average length at different estimated ages of Bigeye Croaker Micropogonias megalops. Sample details are shown / Longitud media en diferentes edades estimadas del Chano norteño Micropogonias megalops. Se muestran los detalles de muestreo

\begin{tabular}{|c|c|c|c|c|c|c|}
\hline \multirow{2}{*}{ Age } & \multicolumn{3}{|c|}{ Average total length } & \multicolumn{3}{|c|}{ Count } \\
\hline & Total & Females & Males & Total & Females & Males \\
\hline 1 & 161.6 & 214.3 & 223.8 & 73 & 21 & 4 \\
\hline 2 & 210.0 & 222.2 & 198.6 & 187 & 109 & 48 \\
\hline 3 & 326.7 & 312.8 & 346.5 & 75 & 44 & 31 \\
\hline 4 & 375.3 & 385.0 & 368.4 & 104 & 43 & 60 \\
\hline 5 & 389.9 & 410.6 & 376.7 & 87 & 34 & 53 \\
\hline 6 & 394.3 & 404.3 & 386.1 & 40 & 18 & 22 \\
\hline 7 & 407.7 & 429.7 & 391.3 & 21 & 9 & 12 \\
\hline 8 & 402.1 & 414.7 & 395.5 & 29 & 10 & 19 \\
\hline 9 & 400.8 & 414.1 & 392.4 & 18 & 7 & 11 \\
\hline 10 & 430.8 & 430.0 & 431.3 & 6 & 2 & 4 \\
\hline 11 & 439.3 & 453.8 & 435.0 & 7 & 4 & 2 \\
\hline 12 & 448.6 & 447.1 & 451.3 & 11 & 7 & 4 \\
\hline 13 & 452.5 & 480.0 & 425.0 & 2 & 1 & 1 \\
\hline 14 & - & - & - & - & - & - \\
\hline 15 & 470.0 & 470.0 & 470.0 & 2 & 1 & 1 \\
\hline 16 & 447.5 & 460.0 & 435.0 & 2 & 1 & 1 \\
\hline
\end{tabular}

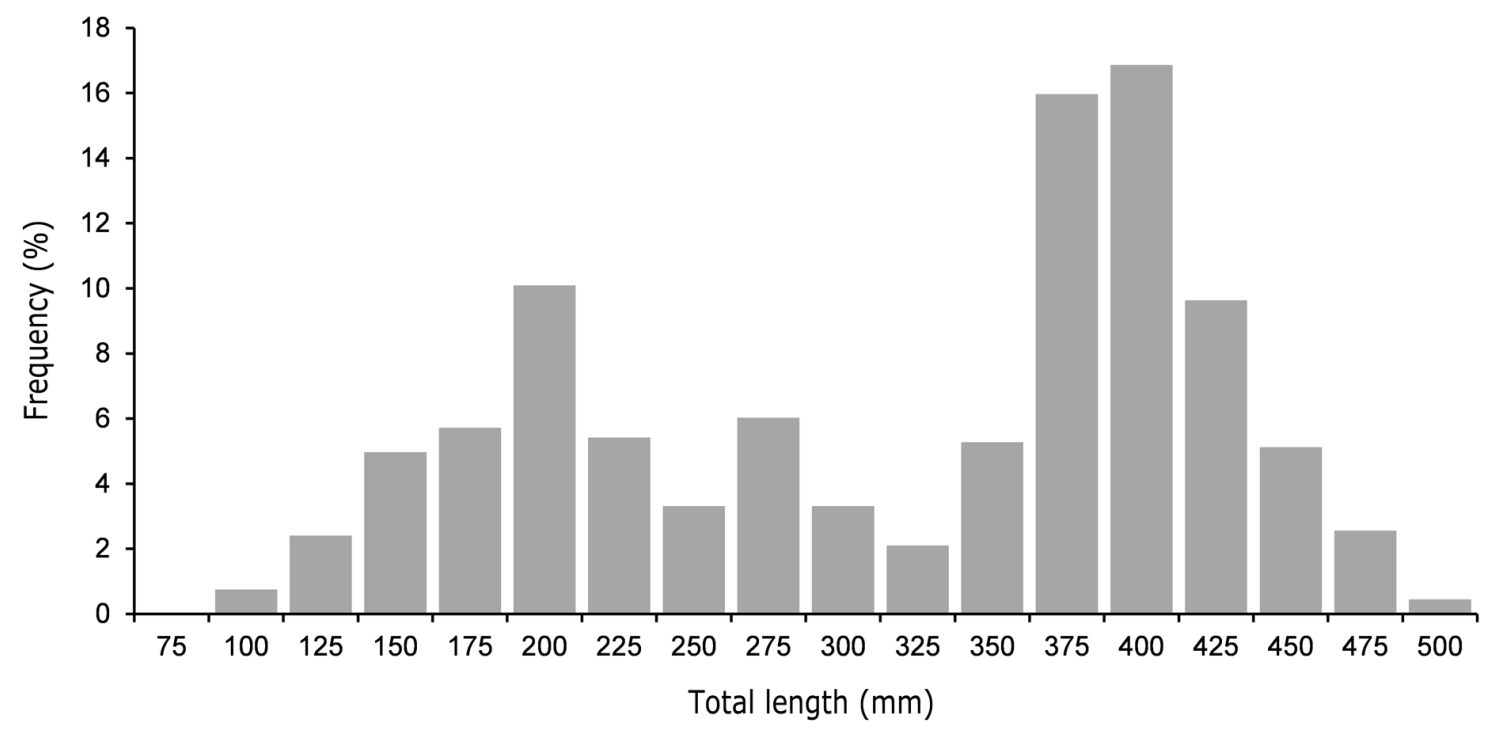

Figure 4. Length frequency distributions of Micropogonias megalops from the Upper Gulf of California / Distribución de las frecuencias de longitud de Micropogonias megalops del Alto Golfo de California 


\begin{abstract}
Table 2. Akaike's information criterion (AIC), number of parameters in each model (K), Akaike differences $\left(\Delta_{\mathrm{i}}\right)$, Akaike weights $\left(W_{i}\right)$, estimated asymptotic length $\left(L_{\infty}\right)$, and the corresponding conditional asymptotic standard error (S.E.) for each candidate model / Criterio de información de Akaike (AIC), número de parámetros en cada modelo (K), diferencias de Akaike $\left(\Delta_{\mathrm{i}}\right)$, ponderaciones de Akaike $\left(\mathrm{W}_{\mathrm{i}}\right)$, longitud asintótica estimada $\left(\mathrm{L}_{\infty}\right)$, y el error estándar (S.E.) que corresponde a la longitud asintótica para cada uno de los modelos candidatos
\end{abstract}

\begin{tabular}{|c|c|c|c|c|c|c|c|}
\hline & Models & $K$ & AIC & $\Delta_{i}$ & $\begin{array}{l}\text { Wi } \\
(\%)\end{array}$ & $\begin{array}{l}\text { Asymptotic } \\
\text { length }(\mathrm{mm})\end{array}$ & S.E. \\
\hline \multirow[t]{5}{*}{ All data } & VBGM & 3 & -6960.7 & 0 & 91.87 & 448 & 1.78 \\
\hline & Schnute & 4 & -6955.8 & 4.8 & 8.13 & 452 & 1.78 \\
\hline & Gompertz & 3 & -6910.1 & 50.5 & 0.00 & 428 & 1.72 \\
\hline & Logistic & 3 & -6979.0 & 81.7 & 0.00 & 419 & 1.68 \\
\hline & Multi-model averaged & & & & & 448.64 & 1.96 \\
\hline \multirow[t]{5}{*}{ Female } & VBGM & 3 & -3291.2 & 0 & 92.7 & 461 & 2.75 \\
\hline & Schnute & 4 & -3286.1 & 5.1 & 7.30 & 478 & 2.74 \\
\hline & Gompertz & 3 & -3266.4 & 24.8 & 0.00 & 453 & 2.64 \\
\hline & Logistic & 3 & -3250.9 & 40.3 & 0.00 & 443 & 2.58 \\
\hline & Multi-model averaged & & & & & 462.41 & 3.95 \\
\hline \multirow[t]{5}{*}{ Males } & VBGM & 3 & -2793.5 & 0 & 99.96 & 429 & 2.47 \\
\hline & Schnute & 4 & -2778 & 15.4 & 0.04 & 424 & 2.41 \\
\hline & Gompertz & 3 & -2754.5 & 39 & 0.00 & 404 & 2.30 \\
\hline & Logistic & 3 & -2739.5 & 54 & 0.00 & 397 & 2.24 \\
\hline & Multi-model averaged & & & & & 428.89 & 1.47 \\
\hline
\end{tabular}

For each model, Table 2 shows the corresponding AIC, $\Delta_{\mathrm{i}}, W_{i}, L_{\infty}$, and the averaged $L_{\infty}$. The VBGM showed the lowest AIC value in the 3 dataset (Total data, females and males). Another important result shown in Table 2 is the Delta value $\left(\Delta_{\mathrm{i}}\right)$ for each models, the $\Delta_{\mathrm{i}}$ values were greater than 10 for the remaining 3 models tested in the males datasets, but in females and total data set, Schnute got 5.1 and 4.8 values, respectively. Females had the highest asymptotic length value with Schnute model $\left(L_{\infty}=478\right.$ $\mathrm{mm})$.

The anticipated growth curves should be different each model, however the 4 growth curves displayed in Fig. 5 have very similar trajectories, that in fact is the expected growth curves of the VBGM. This figure include the Schnute growth model fitted to the data, but the likelihood profiles of the $\theta$ parameters are in Fig. 6. The values were: $l=137(\mathrm{CI}=133-141 \mathrm{~mm} ; P<0.05), \delta=451$ $(\mathrm{CI}=448-455 \mathrm{~mm} ; P<0.05), \lambda=0.4036(\mathrm{CI}=0.394-0.414 ; P$ $<0.05), \rho=0.997(\mathrm{CI}=0.996-0.998 ; P<0.05)$.

The VBGM was the best fitted model to the data (AIC and $W_{i}$ values). For this reason the VBGM fitted data to female and males database are showed only this equation. Fig. 7 shows the growth trajectory the VBGM fitted to female database, and the individually confidence interval and joint confidence contour for $L_{\infty}$ and $k$ parameters. Figure 8 shows the same, but for male's database. The panel ' $d$ ' in both figures (Figs. 7 and 8) shows a wider interval each parameter than individually obtained (panel $\mathrm{b}$ and $\mathrm{c}$, both figures).

\section{Discussion}

The Sciaenidae family (croaker fish) dominates near shore, soft-bottom, estuarine, and freshwater habitats throughout temperate and tropical waters. Because of their abundance and accessibility, they support important commercial, recreational, and artisanal fisheries wherever they are found (Pondella et al. 2008). Therefore, there are many studies of individual growth in other sciaenid species around the world (Pondella et al. 2008, RamosMiranda et al. 2009, Hutchings et al. 2010). In the Gulf of California, there are at least 30 species of Sciaenidae (Chao 1995) but only 3 are endemic; Totoaba Totoaba 


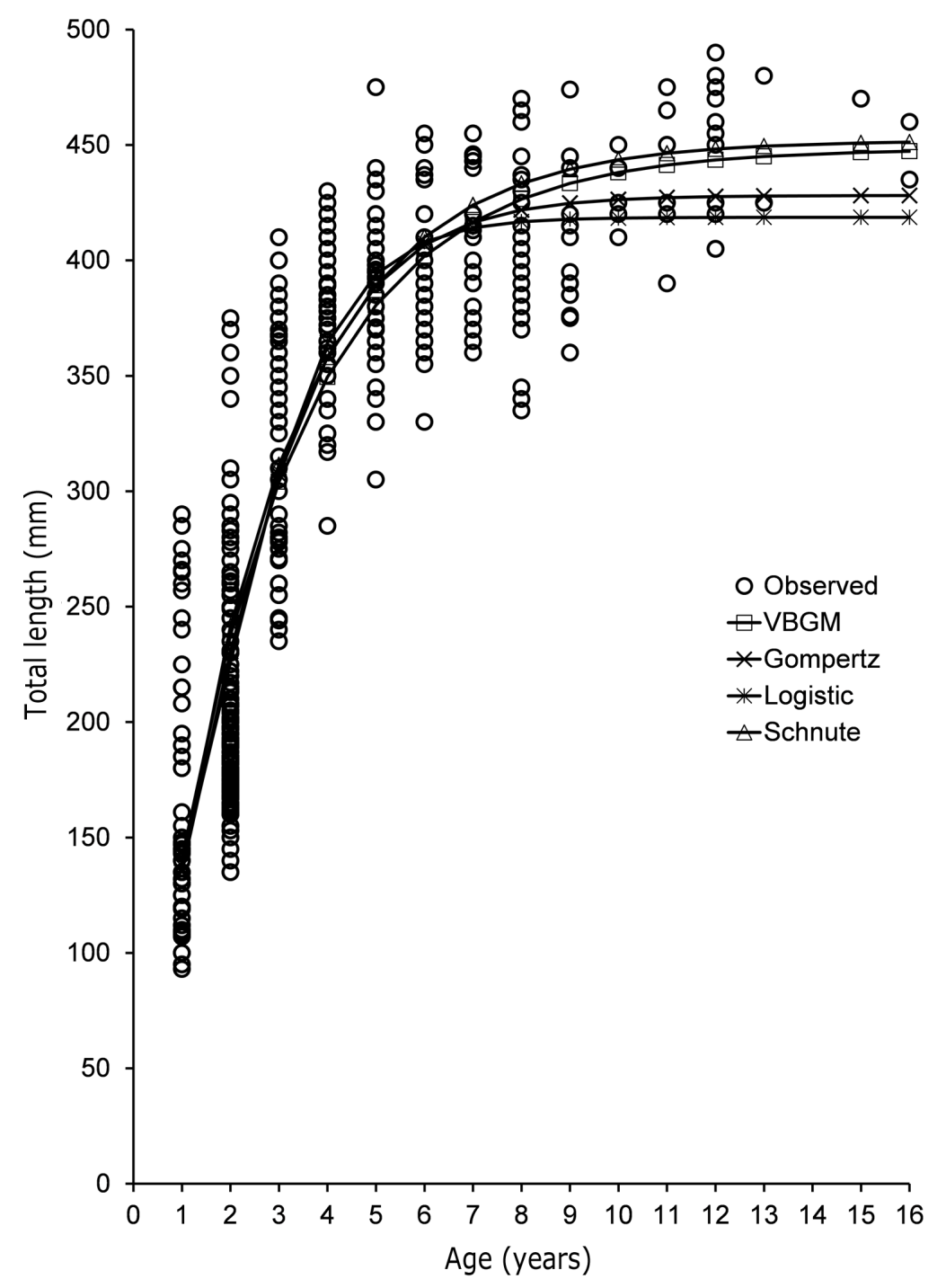

Figure 5. Growth curves generated by the 4 models using total data for Micropogonias megalops from the Upper Gulf of California / Curvas de crecimiento generadas con los 4 modelos usando todos los datos para Micropogonias megalops del Alto Golfo de California

macdonaldi, Gulf corvina Cynoscion othonopterus, and Bigeye Croaker M. megalops. Román-Rodríguez \& Hammann (1997) reported age and growth data for totoaba, and they found that the oldest individual had an asymptotic length of $L_{\infty}=1355 \mathrm{~mm}$ at $25 \mathrm{yrs}$ of age. However, there are 3 studies reporting the growth of gulf corvina $C$. othonopterus that use the VBGM (RománRodríguez 2000, CRIP 2005, Erisman 2012). They reported the oldest gulf corvina to be 9 yrs old; however, different asymptotic lengths were reported in each study (763-985 $\mathrm{mm}$ ). The $M$. megalops appears to be the smallest among sciaenids in the UGC because the highest asymptotic length obtained was $461 \mathrm{~mm}\left(L_{\infty}\right)$ for females. M. megalops appears to have intermediate longevity when compared with other endemic sciaenids from the Gulf of California as the oldest individual was 16 yrs old (the oldest reported C. othonopterus was $9 \mathrm{yrs}$ old and the oldest $T$. macdonaldi was 25 yrs old).

There are 2 previous studies reporting the growth of M. megalops in the UGC. A study by Román-Rodríguez (2000) unfortunately appears to report an inaccuracy in the asymptotic length value, this author present the VBGM embedded in the graph; however, there are discrepancies in the tabulated data and data on the figure. 
a)

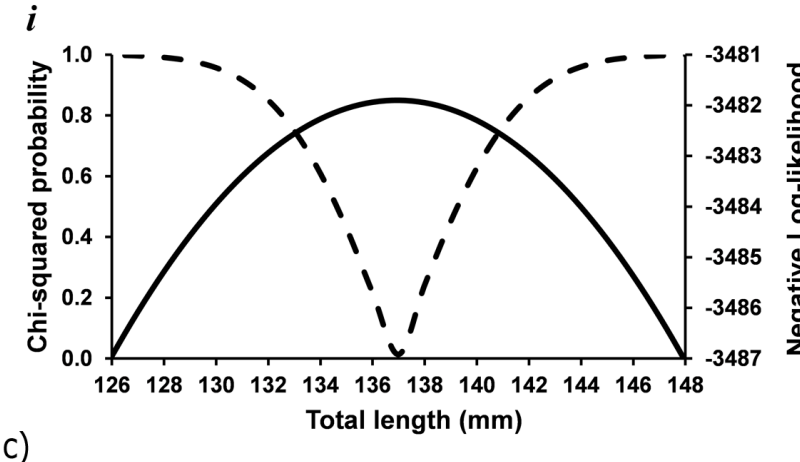

c)

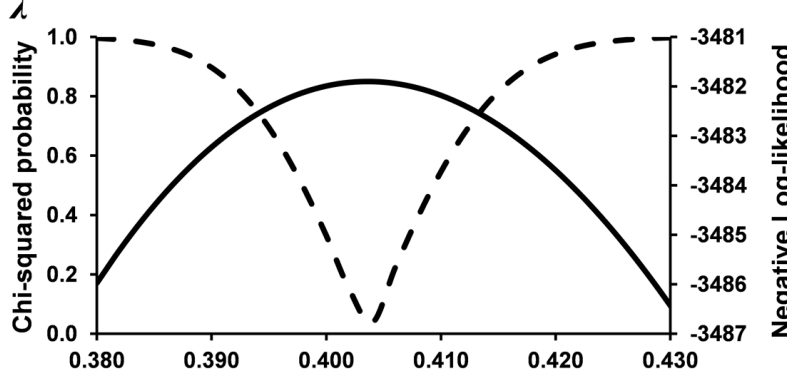

b)

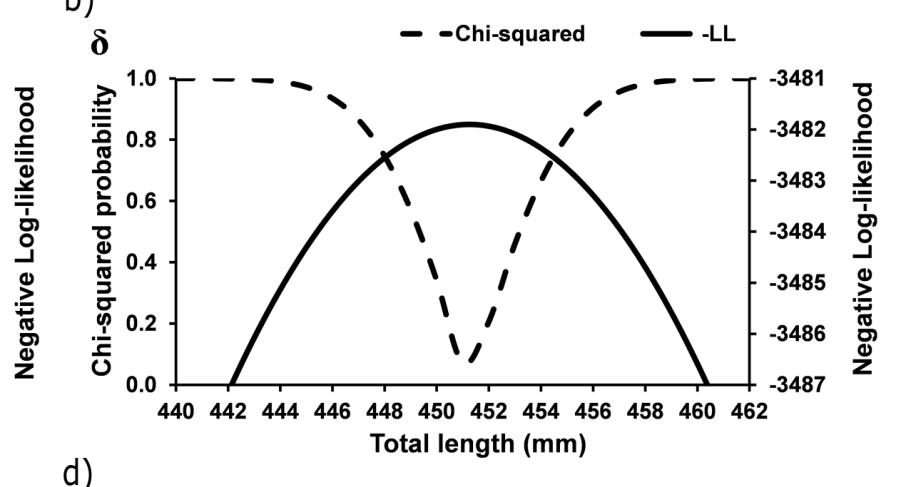

d)

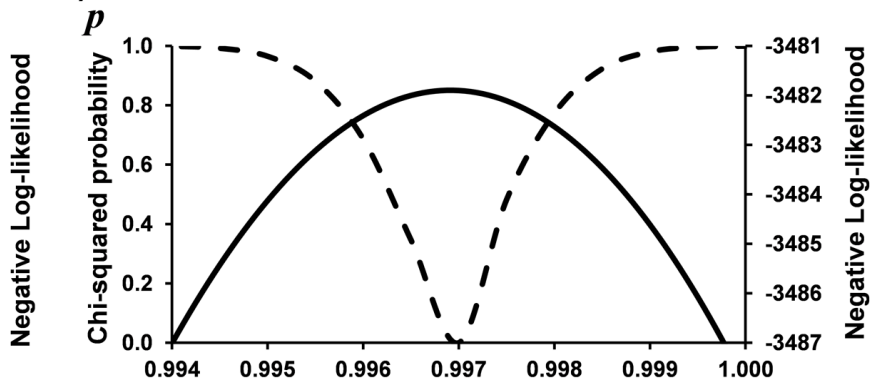

Figure 6. Likelihood profiles of parameters estimated for the Schnute growth model. a) parameter $\boldsymbol{l}$, b) parameter $\delta$, c) parameter $\lambda$ and d) parameter $\rho$ / Perfiles de verosimilitud para los parámetros estimados en el modelo de crecimiento de Schnute. a) parámetro $l$, b) parámetro $\delta$, c) parámetro $\lambda$ y d) parámetro $\rho$

While observed data in table are less than $500 \mathrm{~mm}$ in TL, in the graphic is showed TL higher than $500 \mathrm{~mm}$. In the present study, we used the same data that was used by Román-Rodríguez (2000) but we processed the raw data differently. Thus, it was impossible to compare our results with those of Román-Rodríguez (2000). The other study was development with data from a period elapsed 20102012 (Arzola-Sotelo 2013). This author also refused a comparison his result to those presented by RománRodríguez (2000) for the same reason highlighted above.

A comparison of the present study and Arzola-Sotelo (2013) become remarkable because the present study analyzed data from the same zone than Arzola-Sotelo (2013) but from a different period (1997-1998). Another similarity in the present study and the Arzola-Sotelo (2013) is the use of Multi-model approach with the same 4 models. It is important to mention that Arzola-Sotelo (2013) only present data without separation by sexes. According to Aragón-Noriega et al. (2009) the period of the present was one of low capture (early period of the fishery) and that presented by Arzola-Sotelo (2013) was a period of recovery after high fishery exploitation.
Model selection was performed using the AIC. The advantage of this approach is that the models are hierarchically ordered based on their fit to the data, and the parameters of the candidate models can be averaged. For this procedure, it is necessary to estimate the Akaike weight (Burnham \& Anderson 2002). In the present study and in the Arzola-Sotelo (2013) the best model that fit the data was VBGM and in second place was the Schnute model, the differences in both studies is in the Akaike weight $\left(W_{i}\right)$. In the present study the $W_{i}$ value, in favor to VBGM was $91.87 \%$, and the $W_{i}$ value, in favor to Schnute model was $8.13 \%$. In Arzola-Sotelo (2013) the $W_{i}$ value, in favor to VBGM was $72.85 \%$, and the $W_{i}$ value, in favor to Schnute model was $26.8 \%$. The observation of Burnham \& Anderson (2002), which stated that it is better to declare a best model, only if the $W_{i}$ value is greater than $80 \%$, must be taken into account.

Taken into account the above observation, ArzolaSotelo (2013) decided not to select a single best model. Instead they computed an averaged asymptotic length from the 4 models and obtained a $L_{\infty}=428.7$. They reported the asymptotic length being $439.86 \mathrm{~mm}$ TL for VBGM and 

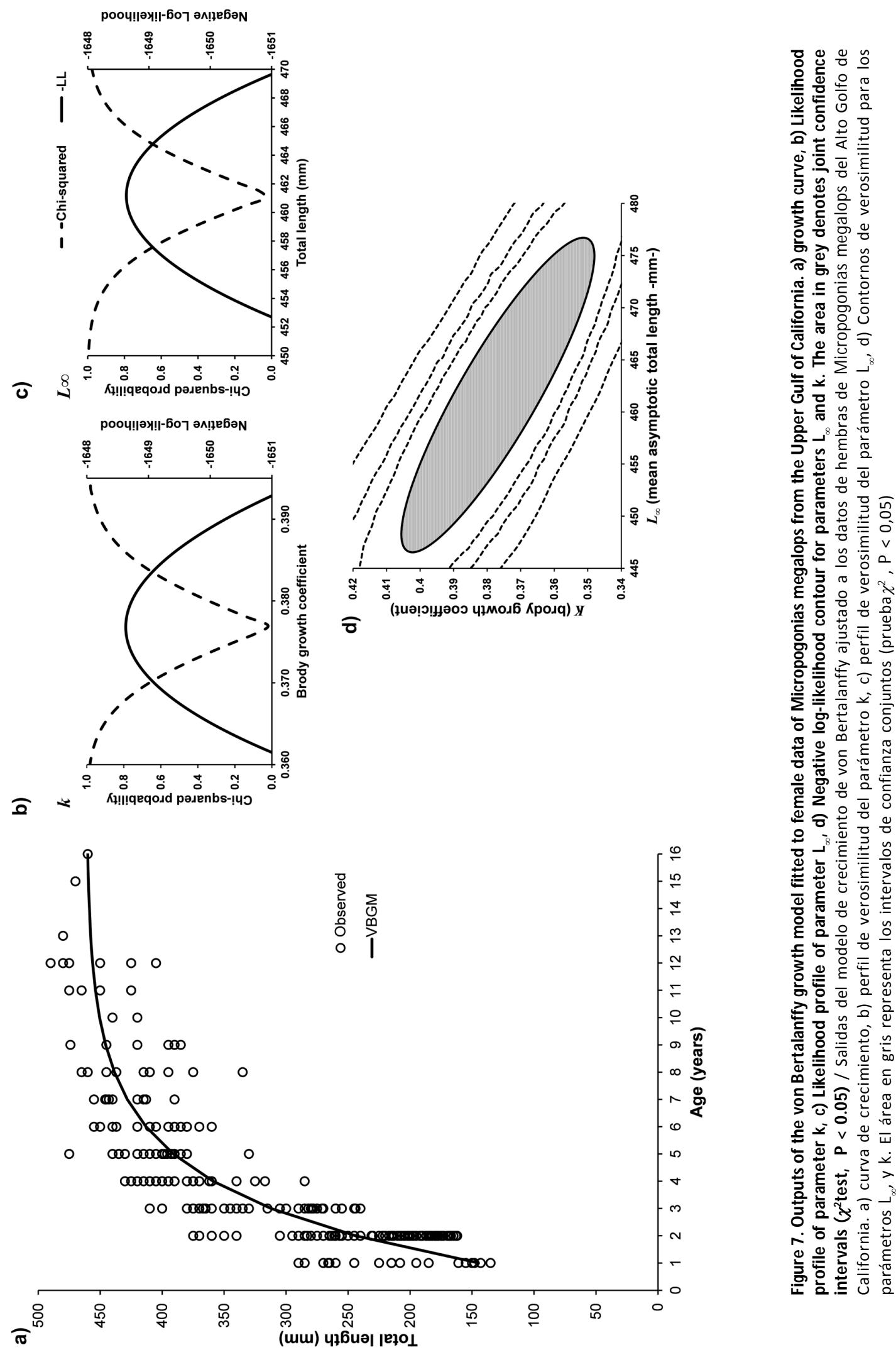

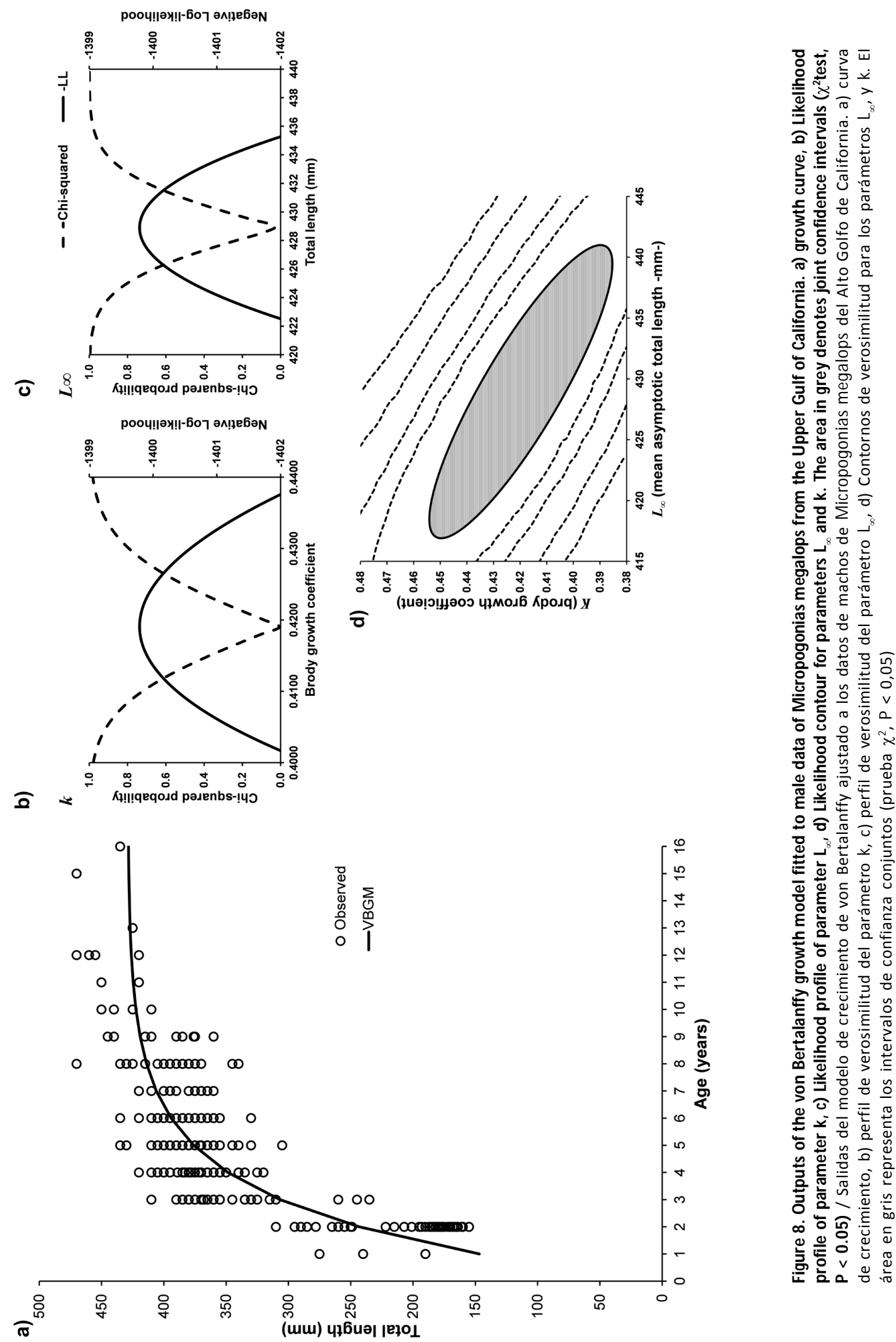

Vol. 50, № 1, 2015 
$398.37 \mathrm{~mm}$ TL for Schnute. In the present study we found the asymptotic length of $448 \mathrm{~mm}$ TL and $452 \mathrm{~mm}$ TL for VBGM and Schnute respectively. After averaged the value was $L_{\infty}=448.64$ because the value $W_{i}=91.87 \%$ in favor to VBGM.

Considering only the averaged value of $L_{\infty}$, in the present study or in the Arzola-Sotelo (2013) study, it is noted that $M$. megalops showed a rapid growth, reaching $237 \mathrm{~mm}$ during the second age-class, which is more than $50 \%$ of the mean asymptotic total length. Cerdenares et al. (2011) mentioned that rapid growth may be an advantage adapted for predator avoidance. In fact, between the third and fourth age-class the $M$. megalops reaching $75 \%$ of the mean asymptotic total length (337 $\mathrm{mm}$ TL)

The Schnute growth model is a 4-parameter model. If we watch over the $\lambda$ and $\rho$ parameters, it may happen that the estimated curve lies close to a 3-parameter submodel. In this case, the 3 parameters submodel become the VBGM if $\rho=1$. In the present study, our estimation this parameter was 0.997 and in Arzola-Sotelo (2013) 1.01. For this reason in our study and in Arzola-Sotelo (2013) study, the trajectories of the curves for Schnute and VBGM resulted very similar. The advantage of the Schnute model is that shows a differential equation forming 8 different curve patterns depending on the parameter values. In this case, for $M$. megalops, showed a growth curve similar to VBGM. The Schnute model is a general 4 parameter growth model that contains most of the preceding growth models as special cases. Rather than modeling the instantaneous rate of change, Schnute concentrates on the relative rate of change. Additionally, Schnute showed a parameterization approach that is statistically stable. The convergence of the nonlinear least squares can be successful when other parameterizations failed to converge. As 2 of the 4 parameters in Schnute's model are expected value parameters $(1, \delta)$, it is would expect a greater stability than for VBGM parameterizations.

In the present study, the Schunte model showed near values of the negative log-likelihood $(-L L)$ in comparison with the VBGM. Also was showed that the VBGM was the best candidate model; however, It is assumed that the age data are sufficiently informative to describe the growth pattern of M. megalops, with either Schnute or VBGM. The $-L L$ were -3481.9 and -3483.3 for Schnute and VBGM respectively, but the AIC penalize that model with more parameter (is the case for Schnute) resulting in AIC of -6955.8 and -6960.7 and consequently and $\Delta_{i}$ value of 4.8 and 0 for Schnute and VBGM, respectively. If the values $\mathrm{l}=137, \delta=451$ and $\lambda=0.4036$ computed for Schnute and fixed $\rho=1$, then the $-L L$ become -3487.8 resulting $\mathrm{AIC}=-6967.6$ and consequently the $\Delta_{\mathrm{i}}$ value of 0 and 7 for Schnute and VBGM, respectively. Thus, Schnute become in the model best fit the data with the Akaike weight of $97.12 \%$.

The VBGM is typically used because it is the best known and most commonly applied length-at-age model Also because it is considered that provides biologically meaningful parameters, unlike other models; however, the case of Schnute model used in the present study have the same physiological baseline than VBGM (Schnute 1981). VBGM is based on metabolic processes (balance between the processes of catabolism and anabolism). The animal growth be considered the result of a balance between synthesis and destruction, and between anabolism and catabolism of the building materials of the body. The organism grows as long as building prevails over breaking down; the organism reaches a steady state if and when both processes are equal. Once again, Schnute model is that shows a differential equation forming 8 different curve patterns depending on the parameter values shows a differential equation forming 8 different curve patterns depending on the parameter values, the Schnute model used in the present study have the same physiological baseline than VBGM (Schnute 1981).

The biological relevance in growth model trajectories was discussed by Karkach (2006). The growth curves used in this study to describe the size increment of $M$. megalops from UGC are parametric functions with different parameters relating to the measure of paired sizeage data. As mentioned above, the mathematical functions used in this study do not reflect the nature and dynamics of the core biological processes (feeding, digestion, assimilation, respiration, excretion). Probably a more general approach to changes in size would be to regards the organism's size as a result of dynamics balance between the accumulations and break-down of biomass (Karkach 2006). The models of growth can be a simple and abstract involving a simplistic description of built up and break-down of organism compounds and tissues, with each of these processes being related to size (Karkach 2006).

The growth coefficient (parameter $k$ for VBGM and $\lambda$ for Schnute) is an important parameter to elucidate about the fishery stress over the species under study. In this case, $M$. megalops from the UGC, the growth coefficient reduced from 1997-1998 (present study $k=0.378, \lambda=0.436$ ) to 2010-2012 $k=0.26, \lambda=0.26$ (Arzola-Sotelo 2013). The 
possible explanation is that the fishing pressure forced the species to divert their energy in purpose of reach sexual maturity at a younger age and size. So far, these assumptions are mere speculations that should be addressed in future work, which relate the foundations of growth estimated in this study with issues of reproduction and environment.

As clearly showed by Ohnishi et al. (2011), if the objective is to describe the growth performance of a species, the best model must be applied. Thus, we conclude that a multi-model approach should replace the default use of a single model, and when possible, only the raw data should be used for modeling the individual growth of fish, such as M. megalops from the UGC.

The present study states the biological baseline of individual growth of bigeye croaker $M$. megalops in the UGC. It is clear that the of bigeye croaker fishery should be based and supported by increasingly accurate assessments. In this case, knowledge of individual growth of bigeye croaker studies can be used to influence subsequent decisions about its fishery management.

\section{ACKNOWLEDGMENTS}

EAAN received financial support from CONACYT (CB2012-1 Project 178727). CONABIO allowed the use of their database Spreadsheet SNIB-CONABIO Project No. L298 (Hoja de cálculo SNIB-CONABIO Proyecto No. L298).

\section{LITERATURE CITED}

Alp A, C Cara, F Ückardes, J Carol \& E García-Brthou. 2011. Age and growth of the Europian catfish (Silurus glanis) in a Turkish Reservoir and comparison with introduced populations. Reviews in Fish Biology and Fisheries 21: 283-329. <doi 10.1007/s11160-010-9168-4>

Aragón-Noriega EA, W Valenzuela-Quiñónez, HM Esparza-Leal, A Ortega-Rubio \& G Rodríguez-Quiroz. 2009. Analysis of management options for artisanal fishing of the Bigeye Croaker Micropogonias megalops (Gilbert, 1890) in the Upper Gulf of California. International Journal of Biodiversity Science and Management 5: 208-214.

Arzola-Sotelo EA. 2013. Aplicación de la teoría de modelos múltiples en la evaluación del crecimiento individual del chano (Micropogonias megalops, Gilbert 1890) en el norte del Golfo de California. Tesis de maestría, Centro de Investigaciones Biológicas del Noroeste, La Paz México, 81 pp.

Baer A, C Schulz, I Traulsen \& J Krieter. 2011. Analyzing the growth of turbot (Psetta maxima) in a commercial recirculation system with the use of three different growth models. Aquaculture International 19: 497-511.
Burnham KP \& DR Anderson. 2002. Model selection and multi-model inference: A practical information-theoretic approach, 488 pp. Springer, New York.

Castro-Aguirre JL. 1978. Catálogo sistemático de los peces que penetran a las aguas continentales de México con aspectos zoogeográficos y ecológicos, 298 pp. Dirección General del Instituto Nacional de Pesca, México.

Cerdenares-Ladrón de Guevara G, E Morales-Bojórquez \& R Rodríguez-Sánchez. 2011. Age and growth of the sailfish Istiophorus platyoterus (Istiophoridae) in the Gulf of Tehuantepec, Mexico. Marine Biology Research 7: 488-499.

Chao LN. 1995. Sciaenidae. Corvinas, barbiches, bombaches, corvinatas, corvinetas, corvinillas, lambes, pescadillas, roncachos, verrugatos. En: Fischer W, F Krupp, W Schneider, C. Sommer, KE Carpenter \& V Niem (eds). Guía FAO para identificación de especies para los fines de la pesca. Pacifico Centro-oriental. Vol.3. Vertebrados, parte II: 1427-1518. FAO, Roma.

CRIP. 2005. Compilación biológico-pesquera de Corvina Golfina, Cynoscion othonopterus en el Alto Golfo de California. Informe Técnico, Centro Regional de Investigaciones Pesqueras, Ensenada, 12 pp.

Cruz-Vásquez R, G Rodríguez-Domínguez, E AlcántaraRazo \& EA Aragón-Noriega. 2012. Estimation of individual growth parameters of the Cortes Geoduck Panopea globosa from the Central Gulf of California using a multimodel approach. Journal of Shellfish Research 31: 725-732.

Cudney R \& P Turk. 1998. Pescando entre mareas del Alto Golfo de California. Puerto Peñasco, México, 166 pp. Centro Intercultural de Estudio de Desiertos y Océanos, Puerto Peñasco.

Erisman BE. 2012. Evaluation of available data, preliminary data-poor assessment and recommendations for the Gulf corvina fishery in the Gulf of California. Technical Report to the Environmental Defense Fund, La Paz, 39 pp.

Galindo-Bect M, EP Glenn, HM Page, K Fitzsimmons, LA Galindo-Bect, JM Hernandez-Ayon, RL Petty, J GarciaHernandez \& D Moore. 2000. Penaeid shrimp landings in the upper Gulf of California in relation to Colorado River freshwater discharge. Fishery Bulletin 98: 222-225.

Hurvich CM \& CL Tsai. 1989. Regression and time series model selection in small samples. Biometrika 76: 297-307.

Hutchings K, MH Griffiths \& SJ Lamberth. 2010. An investigation of the effect of temporal variation in growth rate of Umbrina robinsoni on biological reference point estimates calculated using per-recruit models. African Journal of Marine Science 32: 633-636.

Karkach AS. 2006. Trajectories and models of individual growth. Demographic Research 15: 347-400.

Katsanevakis S. 2006. Modelling fish growth: Model selection, multi-model inference and model selection uncertainty. Fisheries Research 81: 229-235. 
Katsanevakis S \& D Maravelias. 2008. Modelling fish growth: multi-model inference as a better alternative to a priori using von Bertalanffy equation. Fish and Fisheries 9: 178-187.

Mercier L, J Panfili, C Paillon, A N'diaye, D Mouillot \& AM Darnaude. 2011. Otolith reading and multi-model inference for improved estimation of age and growth in the gilthead seabream Sparus aurata (L.). Estuarine, Coastal and Shelf Science 92: 534-545.

Ohnishi S, T Yamakawa, H Okamura \& T Akamine. 2012. A note on the von Bertalanffy growth function concerning the allocation of surplus energy to reproduction. Fisheries Bulletin 110: 223-229.

Pondella DJ, JT Froeschke, LS Wetmore, E Miller, CF Valle \& L Medeiros. 2008. Demographic parameters of Yellowfin Croaker, Umbrina roncador (Perciformes: Sciaenidae), from the Southern California Bight. Pacific Science 62: 555-568.

Ramos-Miranda J, K Bejarano-Hau1, D Flores-Hernández \& LA Ayala-Pérez. 2009. Growth, mortality, maturity, and recruitment of the star drum (Stellifer lanceolatus) in the southern Gulf of Mexico. Ciencias Marinas 35: 245-257.

Ricker WE. 1975. Computation and interpretation of biological statistics of fish populations. Bulletin Fisheries Research Board of Canada 23: 519-529.

Rodríguez-Quiroz G, EA Aragón-Noriega, W ValenzuelaQuiñónez \& HM Esparza-Leal. 2010. Artisanal fisheries in the conservation zones of the Upper Gulf of California. Revista de Biología Marina y Oceanografía 45: 89-98.

Román-Rodríguez MJ. 2000. Estudio poblacional del Chano Norteño, Micropogonias megalops y la Curvina Golfina Cynoscion othonopterus (Gilbert) (Pisces: Sciaenidae), especies endémicas del Alto Golfo de California, México. Instituto del Medio Ambiente y Desarrollo Sustentable del Estado de Sonora. Hoja de cálculo SNIB-CONABIO proyecto No. L298. CONABIO, Distrito Federal, México, 143 pp.
Román-Rodríguez MJ \& MG Hammann. 1997. Age and growth of totoaba Totoaba macdonaldi (Scianidae), in the upper Gulf of California. Fishery Bulletin 95: 620-628.

Schnute J. 1981. A versatile growth model with statistically stable parameters. Canadian Journal of Fisheries and Aquatic Science 47: 24-40.

Schnute J \& K Groot. 1992. Statistical analysis of animal orientation data. Animal Behavioral 43: 15-33.

Schnute J \& LJ Richards. 1990. A unified approach to the analysis of fish growth, maturity, and survivorship data. Canadian Journal of Fisheries and Aquatic Science 47: 2440.

Shono H. 2000. Efficiency of the finite correction of Akaike's information criteria. Fisheries Science 66: 608-610.

Varela-Romero A \& JM Grijalva-Chon. 2004. Allozyme evidence of the bigeye croaker (Micropogonias megalops) fishery collapse in the Upper Gulf of California. Bulletin of Southern California Academic Science 103: 66-78.

Venzon DJ \& SH Moolgavkor. 1988. A method for computing profile-likelihood-based confidence intervals. Applied Statistical 37: 87-94.

Wang Y \& Q Liu. 2006. Comparison of Akaike information criterion (AIC) and Bayesian information criterion (BIC) in selection of stock-recruitment relationships. Fisheries Research 77: 220-225.

Zhu L, L Li \& Z Liang. 2009. Comparison of six statistical approaches in the selection of appropriate fish growth models. Chinese Journal of Oceanology and Limnology 27: 457-467. 